\title{
THE FINANCIAL ACCELERATOR IN EUROPE AFTER THE FINANCIAL CRISIS
}

\author{
Klára Baková ${ }^{1}$ \\ ${ }^{1}$ Mendel University in Brno, Czech Republic
}

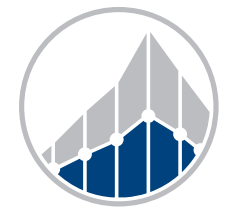

EUROPEAN JOURNAL OF BUSINESS SCIENCE AND TECHNOLOGY

Volume 4 Issue 2 ISSN 2336-6494 www.ejobsat.com

\begin{abstract}
This paper investigates the mechanism of a financial accelerator. In particular, it examines the procyclicality of credit margins in Europe after the financial crisis, with an additional split into small, medium and large-sized banks. The empirical analysis is in contrast with contemporary authors because it approves that the financial accelerator is not present on the European market after the financial crisis. It could be caused by multiple factors, for example structural changes during the financial crisis, a change in the behaviour of commercial banks or extremely low interest rates. We tested our hypothesis on a dataset that consists of a data panel with annual data for the period 1998-2015 and includes 2,489 banks from 36 European countries from the Bankscope database. We also provide robust empirical proof that such behaviour was not occurring during the financial crisis or after the financial crisis in the European banking system.
\end{abstract}

\section{KEY WORDS}

credit cycle, financial accelerator, interest margin

\section{JEL CODES}

C23, E51, G21

\section{INTRODUCTION}

The financial accelerator theory, which originated in the 1990s, was described in the studies of Bernanke and Gertler (1989) and Bernanke et al. (1996). Kiyotaki and Moore (1997) also contributed to the financial accelerator theory and procyclical change in the value of collateral assets. The financial accelerator was empirically tested before the financial crisis and after a financial crisis and confirmed in the USA (Aliaga-Díaz and Olivero, 2010), in Turkey (Turgutlu, 2010) and in Europe (Altunbaş et al., 2016). There is general agreement that the financial accelerator does not exist after a financial crisis. Our paper follows these studies 
and contributes to the current theory of the financial accelerator, which helps to explain the scale and persistence of the business cycle.

The methodology was based on the study of the behaviour of banks' price-cost margins as a proxy for the external finance premium that banks charge to firms. They identified the procyclical impact of credit margins in their results. Procyclical margins make bank loans more expensive during economic downturns and can cause the deepening of the business cycle.

The contribution of this paper is to identify the varied functioning of the financial accelerator after the financial crisis, with an additional split into small, large and medium-sized banks. The research is focused on the procyclical behaviour of interest margins on the European market. It influences the ability of borrowers to obtain loans from external sources. This paper provides robust empirical proof that such behaviour was not occurring in the European banking market during the financial crisis or after the financial crisis. In particular, it examines the relationship between credit margins, the economic cycle and other determinants.

The paper is organised as follows. Section 2 contains the literature review. A detailed overview of methods and data is provided in Sections 3. Section 4 presents the results of the econometric models and Section 5 presents a robustness analysis. Section 6 offers concluding remarks.

\section{LITERATURE REVIEW}

There is an extensive review of literature on the FA, especially during the 1990s. A financial accelerator can be described as a mechanism effect when the effect of relatively small impulses could lead to a persistent fluctuation in the economy due to the role of an endogenously procyclical credit margin in financial markets (Bernanke et al., 1996 and 1998). Due to imperfections in the credit market, the ability of borrowers to obtain credit from external sources is procyclically affected if the economy is hit by a shock that affects the net worth of borrowers (Bernanke and Gertler, 1989; Bernanke et al., 1996 and 1998). The effect may also have procyclical interaction between credit limits and asset prices. Durable assets are presented as factors of production, but also as collateral for loans (Kiyotaki and Moore, 1997).

We follow studies of the financial accelerator in the USA (Aliaga-Díaz and Olivero, 2010), in Turkey (Turgutlu, 2010) and in Europe (Altunbaş et al., 2016). These studies tested the existence of the financial accelerator on the case of cyclical banks' price-cost margins as the dependent variable. Therefore, we provide a brief overview about the history of the financial accelerator as well as the determinants of bank margins.

\subsection{History of the Financial Accelerator}

The financial accelerator theory is part of the theoretical and empirical literature about credit-market imperfections. The origin of the theory was in 1989 when Bernanke and Gertler (1989) and then Bernanke et al. (1996) studied how shocks may be amplified by endogenous developments in the financial markets. Bernanke and Gertler (1989) identified a condition of the borrower's balance sheet as a source of output dynamics. Their concept analyses the mechanism of net worth, which has an impact on agency costs. In short, when, for example, a positive shock occurs, the higher borrower net worth reduces the agency costs, so he can pay a lower premium on external finance because the risk of bankruptcy is lower. It causes an increase in investment. This mechanism amplifies the upturn and a relatively small shock could lead to a persistent shock in the economy.

The question of how credit constraints interact with aggregate economic activity over the business cycle was also studied by Kiyotaki and Moore (1997). They focused on amplifying shocks, the transfer through other sectors and their persistence. As an amplifier of business fluctuations, they identified the prices of the 
assets used as collateral. It interacts with an endogenously defined credit limit and can lead to a large and persistent shock. The theory is basically similar to that of Bernanke and Gertler (1989), but in this case, the change in net worth is due to the availability of credit, not the cost of credit.

In the paper "flight to quality", Bernanke et al. (1996), focused on the beginning position of borrowers. They suggest that borrowers facing relatively high agency costs in credit markets will bear the brunt of an economic downturn. When a shock occurs, they reduce spending, production, and investment and it worsens the effects of recessionary shocks. For high-agency-cost borrowers, small and mediumsized firms with a worse balance sheet are mainly considered. Their procyclical variability is higher and they should react earlier.

The financial accelerator has been studied in recent empirical works. Some of them were focused on the development of the bank interest margin. They assumed the Bernanke and Gertler hypothesis (1989), that the bank credit margin is a proxy for premium external funds, a key element of the model. This margin behaves procyclically and makes bank loans more expensive during economic downturns compared to an economy with constant margins.

The financial accelerator hypothesis was confirmed by Aliaga-Díaz and Olivero (2010) for US banks in the period 1984-2005. Turgutlu (2010) tested the theory in Turkey in the period 2001-2008. The impact of the financial accelerator has also been confirmed. Altunbaş et al. (2016) then studied the European banking system in the period 1989-2012. They found that margins in the European banking system are cyclical with respect to the output gap and total bank loans. Pancrazi et al. (2016) confirmed the existence of the financial accelerator mechanism, but with the addition that it is stronger than originally assessed.

The financial accelerator could be changed after the financial crisis. The impact of a lack of liquidity and a change in asset quality was different because of the heterogeneity in Europe (Fratzscher, 2012). The impact of the banking market structure was also explored by Brissimis and Delis (2010), who provided evidence that heterogeneity observed on the bank level can affect the response to changes in monetary policy. The heterogeneity can be observed through the banking channel before a financial crisis and after a financial crisis (Heryán and Tzeremes, 2017). The changing conditions in the economy also brought changes in monetary policy. The ECB decreased interest rates to a historical minimum. They also responded by increasing credit support and quantitative easing (ECB, 2010).

\subsection{Determinants of Interest Margins}

There are many studies focused on interest margins and their determinants. For example, Kapounek et al. (2017) present the development of interest margins spread as the most important indicator of credit growth. Higher interest rates are therefore associated with a lower supply of loans. Models for the interest margin spread are based on a model proposed by Ho and Saunders (1981). The model assumes banks to be risk averse and that their main contribution is to collect deposits and provide loans. The bank margin is influenced by the uncertainty of the transaction, the structure of the banking market, the degree of banking capitalization and the volatility of interest rates. The model was subsequently modified and supplemented, for example, by the possibility of portfolio diversification on the performance of the banking market (McShane and Sharpe, $1985)$ or the role of operating costs (Maudos and de Guevara, 2004).

Differences in interest margins and bank profitability are reflected in varying determinants, such as bank characteristics, macroeconomic conditions, regulation, and several legal and institutional indicators, as shown by DemirgüçKunt and Huizinga (1999) in their study.

The evolution of interest margins is divided according to the influence of monetary policy and banking regulation, the risks of firms that act as current or potential borrowers and the characteristics of the bank. 
The influence of monetary policy and banking regulation is important to mention because the financial crisis and its consequences have led to changes in regulatory policy because the regulatory framework then proved to be inadequate for achieving financial stability. It was necessary to include unrecovered dimensions like liquidity and the risk of the transmission of shock resulting from various sources (Bank of England, 2011). The existing regulatory framework was also inadequate because it failed to prevent banks from over-risking (Dewatripont et al., 2010). Many central banks have not previously embedded the banking system into their models. They have not seen it as a potential source of friction in the transmission mechanism of monetary policy (Gambacorta and Marques-Ibanez, 2011). A new regulatory framework has been introduced, which is a set of macroprudential regulations to reduce systemic risks. A key element is the creation of a reserve for the accumulation of capital at a time when banks are doing well and the economy is growing and vice versa (Cincotti et al., 2012).

In case of a tightening of monetary policy, banks should respond by reducing the volume of credit, which also affects the amount of the credit margin. This mechanism and its functioning are influenced by the central bank's transmission mechanisms, which can operate in different ways. The change in the market interest rate due to the change in official interest rates is influenced by the confidence and expectations of future developments (Bank of England, 1999), the transparency of the central bank's monetary policy (Papadamou et al., 2015), credibility which increases the efficiency of the transmission mechanism (Levieuge et al., 2018), and the bank's access to alternative financing (Fungáčová et al., 2014). Access to alternative sources is determined by the characteristics of banks such as capital, capitalization and liquidity, but also the structure of the banking sector and the market power of individual financial institutions (Gambacorta, 2005; Matousek and Sarantis, 2009). SanfilippoAzofra et al. (2018) show that banks do not respond to monetary policy in countries with a less developed financial system. In countries with developed financial systems, the efficiency of the banking channel is proven after the financial crisis.

During the financial crisis, interest rates were almost zero and it caused the low efficiency of the banking channel in the transmission of monetary policy. The ability of monetary policy to affect banks' lending activity became very ineffective. At low-interest rates, a bank's expectations about future interest rates are changing significantly (Swanson and Williams, 2014; Apergis and Christou, 2015). Other studies suggest that the banking channel is less efficient in banking systems with large, more liquid and more profitable banks (Matousek and Sarantis, 2009; Gunji and Yuan, 2010; Hou and Wang, 2013). The negative impact of very low-interest rates on the profitability of banks' credit assets by reducing interest rate margins was also confirmed by Borio and Gambacorta (2017). Then Dell'Ariccia and Marquez (2013) also warn that it may have a negative impact on the bank's risk.

The literature bears witness to many papers defining factors which could influence a bank's activities and therefore bank loans. Kučerová and Kapounek (2015) identified the main determinants of bank lending activities in the sample of EU countries. They confirmed the significant impact of macroeconomic shocks, banking controls and institutional variables on European lending activities. Chakraborty and Ray (2006) also show similar results - the level of per capita GDP and investments is higher under the bank-based system compared to the market-based system.

Interest rate margins are also affected by the credit cycle. The lower willingness of banks to borrow during a crisis is caused by higher economic uncertainty, lower liquidity availability on interbank markets, and lower solvency due to weaker balances (Adams-Kane et al., 2015). Changes in credit capacity affect the activity of firms dependent on external financing. As mentioned above, banks also respond to the tightening of monetary policy (Kashyap and Stein (1995). Especially small and less liquid banks with low securities are more responsive to monetary policy shocks (Kashyap and Stein, 
2000). This effect is amplified by endogenous changes in optimism and pessimism (animal spirits; see De Grauwe and Macchiarelli, 2015). Based on these changes, it is possible to observe the paradox of financial instability which was first presented by Borio and Drehmann (2009) and Borio (2011). The instability of the economy is paradoxically growing the most when an economy is at its peak. It's caused by the procyclicality of bank lending and firms' access to funds. Banks reduce credit standards in times of economic growth (Jiménez and Saurina, 2006).

Banks can also be influenced by asset price developments, which are used as collateral, and their reduction is accompanied by a reduction in the availability of credit to those using assets in this way (Jiménez and Saurina, 2006). Carvalho et al. (2015) identified bank distress in connection with a fall in share valuation and subsequent losses. These lead to a reduction in the investments of borrowers with the strongest credit relations with banks.

When examining the determinants of interest margins, the impact of the risk channel and the riskiness of the companies cannot be omitted. There were also changes in this sector after the financial crisis. A new risk channel has been defined which suggests that monetary policy can determine the level of risk in the economy. Too low-interest rates for a long time can cause systemic risk accumulation in the financial sector. This results in financial imbalances caused by reduced aversion to risk from banks and other investors (Borio and Zhu, 2012). Knowledge about the risk channel is still limited, but evidence of the risk channel has been proven in the Eurozone (Maddaloni and Peydró, 2011; Cappiello et al., 2010) or in the US investment-banking sector (Adrian and Shin, 2010). Altunbaş et al. (2010) also consider bank risk with the classic indicators (size, liquidity and capitalization) used to assess the ability and willingness of the bank to provide loans. In particular, it found that banks characterized by lower expected default rates are able to offer a larger amount of credit and to better isolate the supply of loans from monetary policy changes. Banks that include corporate risk are also affected by information asymmetries (Duran and Lozano-Vivas, 2015) followed by moral hazard (Antzoulatos and Tsoumas, 2014). Cincotti et al. (2012) confirmed that the state of affairs also affected the level of interest rates.

The last part of credit margins determinants includes bank characteristics. Gambacorta and Marques-Ibanez (2011) identified the characteristics of banks that have a significant impact on banks' credit activity. According to their results, the decline in credit activity during the crisis was strongest in banks with lower core capital, increased dependence on market liquidity and non-interest income sources. Markovic (2006) includes bank capital because more capitalized banks are more isolated from changes in monetary policy or other shocks, without changing credit activity. Similar results were shown by Borio and Gambacorta (2017).

Important determinants of interest rates and the ability to provide loans also include size, capitalization, efficiency and the liquidity of the bank (Guiso et al., 2002). Altunbaş et al. (2009) and Apergis and Christou (2015) place emphasis on characteristics such as liquidity and capitalization. The assumption that large, liquid and well-capitalized banks have more opportunities to expand their loan portfolio and are less sensitive to monetary policy shocks and policy changes to the interest rate has been confirmed by several other authors (Gambacorta and Mistrulli, 2004; Gambacorta, 2005; Jorge, 2009). We can also mention determinants like management efficiency, which can reduce costs, followed by interest margins (Angbazo, 1997; Hawtrey and Liang, 2008).

We include bank liquidity in our model because holding more liquid assets increases additional costs (Ho and Saunders, 1981). We also include bank specialization because we assume that banks more specialized in deposit react in a relatively less elastic manner and banks are able to separate money from exogenous economic shocks (Berlin and Mester, 1999). As another determinant, we include credit quality. If there is a higher credit default, banks need to increase their credit margins to compensate for the loss (Maudos and de Guevara, 2004). The last 
banking characteristic is capital because more capitalized banks can charge a higher margin, if we assume that liabilities are cheaper than equity. It can be caused due to tax optimization (Lown and Peristiani, 1996; Jorge, 2009; Adrian and Shin, 2010).

\section{DATA AND METHODS}

We use annual data from Bureau van Dijk - Bankscope for 2,489 banks across 36 European countries in the period 1998-2015. The Bankscope database provides detailed data including balance sheets and financial indicators of the banks. We mostly focus on bank margin and bank characteristics. We obtained data on macroeconomic fundamentals from the publicly available Eurostat database (Eurostat, 2017). The macroeconomics and institutional data set is merged with individual bank data.

Data are transformed using a chain index with a base period in 2007. The data are further adjusted for outliers in the $1 \%$ and $99 \%$ percentile. To eliminate the obliquity and accuracy of data, all data are transformed using logs. Descriptive statistics and a crosscorrelation matrix are in Annex.

The financial accelerator was tested before the financial crisis and after the financial crisis, especially using interest margins. Changes in the financial market during the period 19982015 can have an impact on the financial accelerator, so we divide the period and then we will analyse the financial accelerator before the financial crisis and after the financial crisis. Specifically, this paper examines the relationship between interest margins, the economic cycle and other determinants. We focus on the European banking sector. Therefore, we deal with the determinants of interest margins in the economy dependent on the banking sector.

In the analysis, the panel regression model is used. Because of the specific conditions of a particular bank, a fixed-effects model is used. These specifics are not captured in the model and cannot be considered as random. Parameter estimates are calculated using the OLS method.

We assume the following regression:

$$
\operatorname{IRmargins}_{i, t}=c+\sum_{m=1}^{M} \beta_{1} \operatorname{mshocks}_{c, t}+\sum_{n=1}^{B} \beta_{2} \operatorname{bcontrols}_{i, t}+\sum_{s=1}^{S} \beta_{3} \text { insti }+\theta_{t}+\mu_{i}+\varepsilon_{i, t}
$$

In the equation (1), $i$ and $t$ are banks and time, IRmargins $s_{i, t}$ is the bank's net interest margin, mshocks ${ }_{c, t}$ are macroeconomics shocks in the country $c$ and time $t$. It measures the business cycle through the development of GDP. GDP is the main explanatory variable, so we include it in the main model and in every sub-model. The set of variables bcontrols $_{i, t}$ represents selected banking characteristics, including bank liquidity measured as a ratio of liquidity assets to total bank assets and bank specialization measured as the ratio of bank deposits to total bank assets. An additional banking characteristic is credit quality measured as a ratio of loan loss provisions to total loans. The last one is capital measured as the ratio of capital to total bank assets. The last set

of variables, insti, includes determinants of the institutional environment. Finally, we include the time dummy variable, $\theta_{t}$, bank fixed effects, $\mu_{i}$ (special characteristics with different impact for each bank), and a residual, $\varepsilon_{i, t}$.

The mechanism of the financial accelerator starts with a relatively small shock that causes a change in economic activity. Changes in economic activity are included in the model by GDP. When an adverse shock occurs, GDP decreases, it causes a slowdown in sales, a decline in cash flows and internal funds, increasing the amount that a firm must obtain from external financial resources to finance investment projects. Changes that have caused the decline in the net worth of the borrower further exert an external financial premium due to the 
asymmetry of information. An increase in the external financial premium due to the deterioration of the borrower's financial situation and the increase in its risk disrupts the access of businesses and households to credit. In addition, there is a reduction in the value of guarantees. It further reduces debtors' balance sheets, increases their risk, and thus reduces their ability to obtain credit. Firms are forced to reduce their investment, resulting in a negative impact on performance. The changes will also cause fluctuations in banks' credit activity, which again affects investment, expenditure and production, which in turn affects GDP. The result is an increase in the persistence of the original shock and the further deepening of the business cycle.
In the robustness analysis, we check the sensitivity of our analysis in two ways. Firstly, we included bank size criteria. Bank size, liquidity, and capitalization are the main criteria, which determine the interest margin (Guiso et al., 2002). Kapounek et al. (2017) show that the loans of large banks also depend strongly on demand factors like GDP, consumption or unemployment.

We analyse small, large and medium-sized banks (see Tab. 3) separately. We divided the model into these groups according to the percentile. The distinguishing criterion used is the indicator of the total assets of banks modified with respect to GDP to eliminate the impact of the size of the economy.

\section{RESULTS}

Tab. 1 presents OLS results for the bank interest margin. Our main model focuses on the interest margin, which is determined by the economic cycle, bank liquidity, specialization, bank equity and credit quality.

The results present the significant and negative effect of GDP on the interest margin. Thus, higher GDP is associated with a lower interest rate. In other words, the interest margins are higher during an economic downturn. This has a negative impact on firms, because it reduces their ability to obtain loans. It further deepen the economic downturn. We can conclude that interest margins are procyclical, so we can confirm the financial accelerator in the European banking system. Tab. 1 also presents the significant and negative effect of bank liquidity. This confirms our hypothesis of declining interest margins in liquidity growth due to the increase in the cost of holding liquid portfolios. The positive impact of capital (equity to assets) confirms the hypothesis that more capitalized banks can set higher interest margins.

On the contrary, an insignificant variable is the credit quality (loans loss reserve to gross loans), so we do not include it in further models.

In the second step, we divided the model by the period before the financial crisis (column 2 ), during the financial crisis (column 3) and after the financial crisis (column 4). Column 1 presents the undivided model, similarly to Tab. 1. As we mentioned, credit quality is omitted because it is not significant in the first model.

Our results show the financial accelerator is in the European banking system only until the financial crisis. Column (3) and (4) in Tab. 2 shows interest margins are determined by the business cycle, but the financial crisis changed their direction. After the financial crisis, the business cycle had a positive impact on bank interest margins. The business cycle is represented by GDP. Thus, the positive impact on bank interest margins means that when GDP grows, interest margins also increase and loans become more expensive for firms. It could reduce the growth of GDP. This is the main different between Tab. 1, where the business cycle is deepened by the negative impact of the business cycle, known as the financial accelerator.

When we compare the results of the model focusing on the period of the financial crisis (column 3) to the model after the financial crisis (column 4), we can see that the impact of GDP is higher during the financial crisis.

When we compare the results of the undivided model (column 1) to the divided model 
Tab. 1: Analysis of interest margin determinants

\begin{tabular}{|c|c|c|c|c|c|c|}
\hline & 1 & 2 & 3 & 4 & 5 & 6 \\
\hline GDP & $\begin{array}{c}-0.183^{* * *} \\
(0.068)\end{array}$ & $\begin{array}{c}-0.225^{* * *} \\
(0.072)\end{array}$ & $\begin{array}{c}-0.195^{* * *} \\
(0.070)\end{array}$ & $\begin{array}{r}-0.106 \\
(0.065)\end{array}$ & $\begin{array}{r}-0.118 \\
(0.081)\end{array}$ & $\begin{array}{c}-0.131^{*} \\
(0.078)\end{array}$ \\
\hline $\begin{array}{l}\text { Liquid assets } \\
\text { to total assets }\end{array}$ & & $\begin{array}{l}-0.030^{* * *} \\
(0.009)\end{array}$ & & & & $\begin{array}{l}-0.033^{* * *} \\
(0.008)\end{array}$ \\
\hline Deposits to assets & & & $\begin{array}{l}0.220^{* * *} \\
(0.032)\end{array}$ & & & $\begin{array}{c}0.045^{*} \\
(0.024)\end{array}$ \\
\hline Equity to assets & & & & $\begin{array}{l}0.272^{* * *} \\
(0.025)\end{array}$ & & $\begin{array}{l}0.228^{* * * *} \\
(0.027)\end{array}$ \\
\hline $\begin{array}{l}\text { Loans loss reserve } \\
\text { to gross loans }\end{array}$ & & & & & $\begin{array}{c}0.003 \\
(0.008)\end{array}$ & $\begin{array}{c}0.006 \\
(0.008)\end{array}$ \\
\hline Constant & $\begin{array}{l}0.849^{* * *} \\
(0.026)\end{array}$ & $\begin{array}{l}0.785^{* * *} \\
(0.033)\end{array}$ & $\begin{array}{l}0.643^{* * *} \\
(0.021) \\
\end{array}$ & $\begin{array}{l}1.649 * * * \\
(0.078)\end{array}$ & $\begin{array}{l}1.021 * * * \\
(0.051)\end{array}$ & $\begin{array}{l}1.527^{* * * *} \\
(0.087)\end{array}$ \\
\hline Observations & 26,654 & 24,098 & 23,856 & 24,105 & 12,240 & 10,635 \\
\hline$R^{2}$ & 0.065 & 0.068 & 0.071 & 0.122 & 0.102 & 0.160 \\
\hline Number of banks & 2,453 & 2,250 & 2,230 & 2,245 & 1,805 & 1,663 \\
\hline 11 & $-10,345$ & $-7,975$ & $-6,766$ & $-7,615$ & $-1,720$ & -741.9 \\
\hline
\end{tabular}

Tab. 2: Financial accelerator analysed based on the period

\begin{tabular}{|c|c|c|c|c|}
\hline & 1998-2015 & 1998-2007 & $2007-2010$ & 2008-2015 \\
\hline GDP & $\begin{array}{r}-0.120^{*} \\
(0.062)\end{array}$ & $\begin{array}{c}-0.240^{* * *} \\
(0.079)\end{array}$ & $\begin{array}{l}1.302^{* * *} \\
(0.253)\end{array}$ & $\begin{array}{l}0.476^{* * *} \\
(0.130)\end{array}$ \\
\hline Liquid assets to total assets & $\begin{array}{c}-0.029^{* * *} \\
(0.008)\end{array}$ & $\begin{array}{c}-0.011 \\
(0.014)\end{array}$ & $\begin{array}{c}-0.030 \\
(0.020)\end{array}$ & $\begin{array}{c}-0.022^{*} \\
(0.012)\end{array}$ \\
\hline Deposits to assets & $\begin{array}{l}0.070^{* *} \\
(0.033)\end{array}$ & $\begin{array}{c}0.014 \\
(0.049)\end{array}$ & $\begin{array}{r}-0.120^{*} \\
(0.063)\end{array}$ & $\begin{array}{c}0.087 \\
(0.069)\end{array}$ \\
\hline Equity to assets & $\begin{array}{l}0.310^{* * *} \\
(0.023)\end{array}$ & $\begin{array}{l}0.342^{* * *} \\
(0.036)\end{array}$ & $\begin{array}{c}0.012 \\
(0.049)\end{array}$ & $\begin{array}{l}0.189^{* * * *} \\
(0.032)\end{array}$ \\
\hline Constant & $\begin{array}{l}1.728^{* * *} \\
(0.075)\end{array}$ & $\begin{array}{l}1.792^{* * *} \\
(0.126)\end{array}$ & $\begin{array}{l}0.657^{* * *} \\
(0.135)\end{array}$ & $\begin{array}{l}0.974^{* * *} \\
(0.087)\end{array}$ \\
\hline Observations & 23,748 & 9,597 & 3,044 & 11,217 \\
\hline$R^{2}$ & 0.148 & 0.148 & 0.058 & 0.034 \\
\hline Number of banks & 2,219 & 1,560 & 1,612 & 2,061 \\
\hline ll & $-5,488$ & 655.3 & 930.6 & $-1,334$ \\
\hline
\end{tabular}

(columns 2-4 according to period), we can see that the impact of liquid assets and specialization is not significant throughout the period. However, the impact of bank liquidity is approximately similar to that of the original model.

\section{ROBUSTNESS ANALYSIS}

The results of the robustness analysis by the size of the banks shows that interest margins are procyclical only in the case of a large bank. The results are in line with the literature - large banks can better diversify, it leads to lower credit default and then lower credit costs and margins. Our robustness analysis results also confirm our previous results about liquid assets and capital, especially in the case of large banks.

Moreover, the impact of capital (equity to assets) is significant before the financial crisis and after the financial crisis and for all bank 
Tab. 3: Results of robustness analysis by the size of the banks

\begin{tabular}{|c|c|c|c|c|}
\hline & All banks & Small banks & Medium banks & Large banks \\
\hline GDP & $\begin{array}{c}-0.120^{*} \\
(0.062)\end{array}$ & $\begin{array}{c}-0.275 \\
(0.169)\end{array}$ & $\begin{array}{c}-0.082 \\
(0.106)\end{array}$ & $\begin{array}{c}-0.187^{* *} \\
(0.089)\end{array}$ \\
\hline Liquid assets to total assets & $\begin{array}{c}-0.029^{* * *} \\
(0.008)\end{array}$ & $\begin{array}{c}-0.009 \\
(0.014)\end{array}$ & $\begin{array}{c}-0.027^{* *} \\
(0.012)\end{array}$ & $\begin{array}{c}-0.048^{* * *} \\
(0.014)\end{array}$ \\
\hline Deposits to assets & $\begin{array}{l}0.070^{* *} \\
(0.033)\end{array}$ & $\begin{array}{c}0.015 \\
(0.043)\end{array}$ & $\begin{array}{c}0.045 \\
(0.043)\end{array}$ & $\begin{array}{c}0.034 \\
(0.022)\end{array}$ \\
\hline Equity to assets & $\begin{array}{l}0.310^{* * *} \\
(0.023)\end{array}$ & $\begin{array}{l}0.267^{* * *} \\
(0.045)\end{array}$ & $\begin{array}{l}0.352^{* * *} \\
(0.037)\end{array}$ & $\begin{array}{l}0.293^{* * *} \\
(0.037)\end{array}$ \\
\hline Constant & $\begin{array}{l}1.728^{* * *} \\
(0.075)\end{array}$ & $\begin{array}{l}1.295^{* * *} \\
(0.121)\end{array}$ & $\begin{array}{l}1.489^{* * *} \\
(0.094)\end{array}$ & $\begin{array}{l}1.232^{* * *} \\
(0.100)\end{array}$ \\
\hline Observations & 23,748 & 5,860 & 8,818 & 7,438 \\
\hline$R^{2}$ & 0.148 & 0.161 & 0.157 & 0.175 \\
\hline Number of banks & 2,219 & 632 & 695 & 595 \\
\hline 11 & $-5,488$ & $-1,332$ & $-2,085$ & -511.9 \\
\hline
\end{tabular}

Tab. 4: Robustness analysis by country

\begin{tabular}{|c|c|c|c|c|}
\hline & EU 36 & CEES & Eurozone & EU 5 \\
\hline GDP & $\begin{array}{c}-0.120^{*} \\
(0.062)\end{array}$ & $\begin{array}{c}-0.058 \\
(0.160)\end{array}$ & $\begin{array}{l}0.467^{* * *} \\
(0.063)\end{array}$ & $\begin{array}{l}0.327^{* *} \\
(0.157)\end{array}$ \\
\hline Liquid assets to total assets & $\begin{array}{c}-0.029 * * * \\
(0.008)\end{array}$ & $\begin{array}{c}-0.009 \\
(0.017)\end{array}$ & $\begin{array}{c}-0.044^{* * *} \\
(0.013)\end{array}$ & $\begin{array}{c}-0.046^{* * *} \\
(0.011)\end{array}$ \\
\hline Deposits to assets & $\begin{array}{l}0.070^{* *} \\
(0.033)\end{array}$ & $\begin{array}{c}-0.073^{* *} \\
(0.035)\end{array}$ & $\begin{array}{l}0.168^{* *} \\
(0.065)\end{array}$ & $\begin{array}{l}0.130^{* *} \\
(0.053)\end{array}$ \\
\hline Equity to assets & $\begin{array}{l}0.310^{* * *} \\
(0.023)\end{array}$ & $\begin{array}{l}0.259^{* * *} \\
(0.051)\end{array}$ & $\begin{array}{l}0.288^{* * *} \\
(0.055)\end{array}$ & $\begin{array}{l}0.279 * * * \\
(0.031)\end{array}$ \\
\hline Constant & $\begin{array}{l}1.728^{* * *} \\
(0.075)\end{array}$ & $\begin{array}{l}2.297^{* * *} \\
(0.194)\end{array}$ & $\begin{array}{l}1.294^{* * *} \\
(0.152)\end{array}$ & $\begin{array}{l}1.734^{* * *} \\
(0.101)\end{array}$ \\
\hline Observations & 23,748 & 2,194 & 9,585 & 14,911 \\
\hline$R^{2}$ & 0.148 & 0.302 & 0.143 & 0.112 \\
\hline Number of banks & 2,219 & 223 & 684 & 1,266 \\
\hline 11 & $-5,488$ & -456.8 & 374.1 & $-3,674$ \\
\hline
\end{tabular}

sizes. Thus, we can confirm the hypothesis that banks which are more capitalized can set higher interest margins for all banks almost independently of the size. The positive impact of bank capital is unchanged throughout.

Secondly, we check the sensitivity of our analysis according to the different groups of European countries - Central and Eastern European countries (CEES), the euro area and the 5 biggest countries (EU 5) in Europe according to GDP. Column 1 presents the undivided model, similarly to Tab. 1 . The results of the robustness analysis by country confirm our previous results of the divided model. In the euro area and the 5 biggest countries, the economic cycle has a positive impact on interest margins. Therefore, we cannot prove the effectiveness of the financial accelerator. 


\section{DISCUSSION AND CONCLUSIONS}

The contribution of this paper is to identify the varied functioning of the financial accelerator before the financial crisis and after the financial crisis and subsequently for the different sizes of banks. The paper is mainly focused on the relationship between interest margins, the economic cycle and other determinants such as bank liquidity or bank capital.

We show that our results of the first undivided model are in line with the current literature and confirm the presence of the financial accelerator in the European banking system. This means procyclical interest margins, which deepen the economic cycle. We also divided our model into 3 periods and according to this model, the financial accelerator is present in the European banking system only until the year 2007, when the financial crisis began. Consequently, economic activity has no procyclical impact on the interest margins after the financial crisis.

There are several reasons why the financial accelerator has not been proven in the European market since the financial crisis. During the crisis, there were many structural changes that led to changes in the instruments used by central banks, but also changes in the behaviour of commercial banks due to increased risk. Extremely low interest rates could have had an important impact. Banks and businesses could have played their role during the crisis. Besides the financial crisis, the banking system also weakened the transmission mechanism, due to deregulation, financial innovations and changes in bank business models. The effects on the financial accelerator may also have changes in the focus on macro-prudential policy or greater emphasis on risk measurement and understanding in the financial sector. In the context of risk control, several new institutions are also involved in monitoring systemic risk and issuing recommendations.

Finally, we presented a robustness analysis to identify the significant impact of the bank size on the financial accelerator in the European market. Our results show the presence of the financial accelerator in the European banking system only in the case of large banks. We also examined other characteristics and, for example, we can confirm the hypothesis that more capitalized banks can set higher interest margins for all banks almost independently of the size.

Then we examined the presence of the financial accelerator in different groups of countries CEES, the euro area and the 5 biggest countries in Europe. We found a significant result in the case of the euro area and the 5 biggest countries in Europe and we did not find a procyclical impact of interest margins.

\section{REFERENCES}

Adams-Kane, J., JiA, Y. and Lim, J. J. 2015. Global Transmission Channels for International Bank Lending in the 2007-09 Financial Crisis. Journal of International Money and Finance, 56, 97-113.

Adrian, T. and Shin, H. S. 2010. Liquidity and Leverage. Journal of Financial Intermediation, 19 (3), 418-437.

Aliaga-Díaz, R. and Olivero, M. P. 2010. Is There a Financial Accelerator in US Banking? Evidence from the Cyclicality of Banks' Price--cost Margins. Economics Letters, 108 (2), 167-171.

Altunbaş, Y., di Tommaso, C. and Thornton, J. 2016. Is There a Financial Accelerator in European Banking? Finance Research Letters, 17, 218-221.
Altunbaş, Y., Gambacorta, L. and MarquesIBANEZ, D. 2009. Securitisation and the Bank Lending Channel. European Economic Review, 53 (8), 996-1009.

Altunbaş, Y., Gambacorta, L. and MarquesIBANEZ, D. 2010. Bank Risk and Monetary Policy. Journal of Financial Stability, 6 (3), 121-129.

Angbazo, L. 1997. Commercial Bank Net Interest Margins, Default Risk, Interest Rate Risk and Off-balance Sheet Banking. Journal of Banking 8 Finance, 21 (1), 55-87. 
Antzoulatos, A. A. and Tsoumas, C. 2014. Institutions, Moral Hazard and Expected Government Support of Banks. Journal of Financial Stability, 15, 161-171.

Apergis, N., Christou, C. 2015. The Behaviour of the Bank Lending Channel when Interest Rates Approach the Zero Lower Bound: Evidence from Quantile Regressions. Economic Modelling, 49, 296-307.

Bank of England. 1999. The Transmission Mechanism of Monetary Policy. Bank of England Quarterly Bulletin [online]. Available at: https://www. bankofengland.co.uk/-/ media/boe/files/quarterly-bulletin/1999/ the-transmission-mechanism-of-monetary-policy.

Bank of England. 2011. Instruments of Macroprudential Policy. Bank of England Discussion Paper.

Berlin, M. and Mester, L. J. 1999. Deposits and Relationship Lending. Review of Financial Studies, 12 (3), 579-607.

Bernanke, B. and Gertler, M. 1989. Agency Costs, Net Worth and Business Fluctuations. American Economic Review, 79 (1), 14-31.

Bernanke, B., Gertler, M. and Gilchrist, S. 1996. The Financial Accelerator and the Flight to Quality. The Review of Economics and Statistics, 78 (1), 1-15.

Bernanke, B., Gertler, M. and Gilchrist, S. 1998. The Financial Accelerator in a Quantitative Business Cycle Framework. NBER Working Paper No. 6455 .

BorIo, C. 2011. Rediscovering the Macroeconomic Roots of Financial Stability Policy: Journey, Challenges and a Way Forward. BIS Working Paper No. 354.

Borio, C. and Drehmann, M. 2009. Towards an Operational Framework for Financial Stability: 'Fuzzy' Measurement and Its Consequences. BIS Working Papers No. 284.

Borio, C. and Gambacorta, L. 2017. Monetary Policy and Bank Lending in a Low Interest Rate Environment: Diminishing Effectiveness? Journal of Macroeconomics, 54 (B), 217-231.

Borio, C. and ZHU, H. 2012. Capital Regulation, Risk-taking and Monetary Policy: A Missing Link in the Transmission Mechanism? Journal of Financial Stability, 8 (4), 236-251.

Brissimis, S. N. and Delis, M. D. 2010. Bank Heterogeneity and Monetary Policy Transmission. ECB Working Paper No. 1233.

Cappielo, L., Kadareja, A., Sørensen, C. K. and ProtopapA, M. 2010. Do Bank Loans and Credit Standards Have an Effect on Output? A Panel Approach for the Euro Area. ECB Working Paper No. 1150.
Carvalho, M., Ferreira, M. A. and Matos, P. 2015. Lending Relationships and the Effect of Bank Distress: Evidence from the 2007-2009 Financial Crisis. Journal of Financial and Quantitative Analysis, 50 (6), 1165-1197.

Chakraborty, S. and Ray, T. 2006. Bank-Based versus Market-Based Financial Systems: A Growth-Theoretic Analysis. Journal of Monetary Economics, 53 (2), 329-350.

Cincotti, S., Raberto, M. and Teglio, A. 2012. Macroprudential Policies in an Agent-Based Artificial Economy. Revue de l'OFCE, 124 (5), 205-234.

De Graume, P. and Macchiarelli, C. 2015. Animal Spirits and Credit Cycles. Journal of Economic Dynamics and Control, 59, 95-117.

Dell'Ariccia, G. and Marquez, R. 2013. Interest Rates and the Bank Risk Taking Channel. Annual Review of Financial Economics, 5 (1), 123-141.

DemirgüÇ-Kunt, A. and Huizinga, H. 1999. Determinants of Commercial Interest Margins and Profitability: Some International Evidence. World Bank Economic Review, 13 (2), 379-408.

Dewatripont, M., Rochet, J.-C. and Tirole, J. 2010. Balancing the Banks: Global Lessons from the Financial Crisis. Princeton University Press, Princeton, Oxford. ISBN 978-0-691-14523-5.

Duran, M. A. and Lozano-Vivas, A. 2015. Moral Hazard and the Financial Structure of Banks. Journal of International Financial Markets, Institutions and Money, 34, 28-40.

ECB. 2010. The ECB's Response to the Financial Crisis. ECB Monthly Bulletin, 10, 59-74 [online]. Available at: https://www.ecb.europa.eu/pub/ pdf/other/art1_mb201010en_pp59-74en.pdf.

Eurostat. 2017. Data [online]. Available at: http://ec.europa.eu/eurostat/data/database. [Accessed 2017, November 9].

Fratzscher, M. 2012. Capital Flows, Push versus Pull Factors and the Global Financial Crisis. Journal of International Economics, 88 (2), 341-356.

Fungáčová, Z., Solanko, L. and Weill, L. 2014. Does Competition Influence the Bank Lending Channel in the Euro Area? Journal of Banking \& Finance, 49, 356-366.

Gambacorta, L. and Marques-Ibanez, D. 2011. The Bank Lending Channel: Lessons from the Crisis. Economic Policy, 26 (66), 135-182.

Gambacorta, L. 2005. Inside the Bank Lending Channel. European Economics Review, 49 (7), 1737-1759.

Gambacorta, L. and Mistrulli, P. E. 2004. Does Bank Capital Affect Lending Behavior? Journal of Financial Intermediation, 13 (4), 436-457. 
Gunj, H. and YuAn, Y. 2010. Bank Profitability and the Bank Lending Channel: Evidence from China. Journal of Asian Economics, 21 (2), 129-141.

Guiso, L., Kashyap, A. K., Panetta, F. and Terlizzese, D. 2002. How Interest Sensitive is Investment? Very (When the Data Are Well Measured). Presented at the NBER Summer Institute, Capital Markets in the Economy Workshop. Available at: http: //www. nber.org/ confer/2002/si2002/guiso.pdf.

Hawtrey, K. and Liang, H. 2008. Bank Interest Margins in OECD Countries. North American Journal of Economics and Finance, 19 (3), 249-260.

Heryán, T. and Tzeremes, P. G. 2017. The Bank Lending Channel of Monetary Policy in EU Countries During the Global Financial Crisis. Economic Modelling, 67, 10-22.

Ho, T. S. Y. and SAunders, A. 1981. The Determinants of Bank Interest Margins: Theory and Empirical Evidence. Journal of Financial and Quantitative Analysis, 16 (4), 581-600.

Hou, X. and WANG, Q. 2013. Implications of Banking Marketization for the Lending Channel of Monetary Policy Transmission: Evidence from China. Journal of Macroeconomics, 38 (B), 442-451.

Jiménez, G. and SAurina, J. 2006. Credit Cycles, Credit Risk, and Prudential Regulation.

International Journal of Central Banking, 2 (2), 65-98.

Jorge, J. 2009. Why Do Bank Loans React with a Delay to Shifts in Interest Rates? A Bank Capital Explanation. Economic Modelling, 26 (5), 799-806.

Kapounek, S., Kučerová, Z. and Fidrmuc, J. 2017. Lending Conditions in EU: The Role of Credit Demand and Supply. Economic Modelling, 67, 285-293.

Kashyap, A. K. and Stein, J. C. 1995. The Impact of Monetary Policy on Bank Balance Sheets. Carnegie-Rochester Conference Series on Public Policy, 42, 151-195.

Kashyap, A. K. and Stein, J. C. 2000. What Do a Million Banks Have to Say About the Transmission of Monetary Policy? The American Economic Review, 90 (3), 407-428.

Kučerová, Z. and KapouneK, S. 2015. Determinants of Bank Lending Activities in the European Union Countries: Is There Any Difference between Bank-Based and Market-Based Systems? In Economic Policy in the European Union Member Countries, pp. 315-326. ISBN 978-80-248-3796-3.
Kiyotaki, N. and Moore, J. 1997. Credit Cycles. Journal of Political Economy, 105 (2), 211-248.

Levieuge, G., Lucotte, Y. and Ringuedé, S. 2018. Central Bank Credibility and the Expectations Channel: Evidence Based on a New Credibility Index. Review of World Economics, 154 (3), 493-535.

Lown, C. and Peristiani, S. 1996. The Behavior of Consumer Loan Rates During the 1990 Credit Slowdown. Journal of Banking \& Finance, 20 (10), 1673-1694.

Maddaloni, A. and Peydró, J.-L. 2011. Bank Risk-Taking, Securitization, Supervision and Low Interest: Rates Evidence from the Euro Area and the U.S. Lending Standards. Review of Financial Studies, 24 (6), 2121-2165.

Markovic, B. 2006. Bank Capital Channels in the Monetary Transmission Mechanism. Bank of England Working Paper No. 313.

Matousek, R. and Sarantis, N. 2009. The Bank Lending Channel and Monetary Transmission in Central and Eastern European Countries. Journal of Comparative Economics, 37 (2), 321-334.

Maudos, J. and de Guevara, J. F. 2004. Factors Explaining the Interest Margin in the Banking Sectors of the European Union. Journal of Banking \& Finance, 28 (9), 2259-2281.

McShane, R. W. and Sharpe, I. G. 1985. A Time Series/Cross Section Analysis of the Determinants of Australian Trading Bank Loan/Deposit Interest Margins. Journal of Banking \& Finance, 9 (1), $115-136$.

Pancrazi, R., Seonee, H. D. and Vukotic, M. 2016. The Price of Capital and the Financial Accelerator. Economics Letters, 149, 86-89.

Papadamou, S., Sidiropoulos, M. and Spyromitros, E. 2015. Central Bank Transparency and the Interest Rate Channel: Evidence from Emerging Economies. Economic Modelling, 48, 167-174.

Sanfilippo-Azofra, S. S., Torre-Olmo, B., Cantero-Saiz, M. and López-Gutiérrez, C. 2018. Financial Development and the Bank Lending Channel in Developing Countries. Journal of Macroeconomics, 55, 215-234.

Swanson, E. T. and Williams, J. C. 2014. Measuring the Effect of the Zero Lower Bound on Mediumand Longer-Term Interest Rates. American Economic Review, 104 (10), 3154-3185.

Turgutuu, E. 2010. Cyclical Behavior of Price-cost Margins in the Turkish Banking Industry. Economic Modelling, 27, 368-374. 


\section{ANNEX}

Tab. 5: Descriptive statistics

\begin{tabular}{lccccc}
\hline Variable & Observations & Mean & Std. deviation & Min. & Max. \\
\hline Interest margin & 27,190 & 2.7265 & 10.128 & -353.53 & 812.50 \\
GDP & 44,784 & 0.9242 & 0.1742 & 0.2706 & 1.6108 \\
Liquid assets to total assets & 24,685 & 0.2311 & 0.2233 & -0.0509 & 1.0000 \\
Deposits to assets & 24,409 & 0.7981 & 0.1875 & 0.0000 & 1.8684 \\
Equity to assets & 24,741 & 0.1028 & 0.1204 & -2.5062 & 1.0000 \\
Loan loss reserve to gross loans & 12,468 & 4.2432 & 6.7056 & -0.3880 & 100.00 \\
\hline
\end{tabular}

Tab. 6: Cross-correlation matrix

\begin{tabular}{|c|c|c|c|c|c|c|}
\hline Variable & $\begin{array}{l}\text { Interest } \\
\text { margin }\end{array}$ & GD & $\begin{array}{l}\text { Liquid assets } \\
\text { to total assets }\end{array}$ & $\begin{array}{l}\text { Deposits } \\
\text { to assets }\end{array}$ & $\begin{array}{c}\text { Equity } \\
\text { to assets }\end{array}$ & $\begin{array}{l}\text { Loan loss reserve } \\
\text { to gross loans }\end{array}$ \\
\hline Interest margin & 1.000 & & & & & \\
\hline GDP & -0.131 & 1.000 & & & & \\
\hline Liquid assets to total assets & -0.188 & -0.098 & 1.000 & & & \\
\hline Deposits to assets & 0.183 & 0.009 & 0.046 & 1.000 & & \\
\hline Equity to assets & 0.346 & 0.064 & 0.022 & -0.130 & 1.000 & \\
\hline Loan loss reserve to gross loans & 0.341 & -0.039 & 0.130 & 0.053 & 0.162 & 1.000 \\
\hline
\end{tabular}

\section{AUTHOR'S ADDRESS}

Klára Baková, Mendel University in Brno, Faculty of Business and Economics, Zemědělská 1, 61300 Brno, Czech Republic, e-mail: kbakova@seznam.cz 